\title{
new
}

\section{perspectives on}

\section{turkey}

\section{vol.1, no. 1 fall, 1987}




\section{NEW PERSPECTIVES ON TURKEY}

\section{Editorial Review Board}

Feroz Ahmad University of Massachusetts-Boston, Tosun Arıcanl Harvard University, Erol Balkan Hamilton College, Günseli Berik New School for Social Research, Nilüfer Çağatay New School for Social Research, Peter Cocks Simon's Rock of Bard College, Engin Derkunt Hofstra Liniversity. Sedef Erk Clark University, Korkut Ertürk New School for Social Research, Fatma Gök, Fitnat Gök, Vedit İnal Hofstra University, Cemal Kafadar Princeton University, Aykut Kansu MIT, Ömer Karasapan New York University, Çă̆lar Keyder SUNY-Binghamton, Gün Kut, James Monsonis Simon's Rock of Bard College, Leyla Neyzi Cornell University, Şule Özler UCLA, Şevket Pamuk Villanova University, Donald Quataert University of Houston, Insan Tunalı Cornell University. Fuat Yalın University of ConnecticutStorrs, Birol Yeşilada University of Missouri-Columbia

\section{Managing Editors:}

Cihan Bilginsoy Vassar College, Department of Economics, Poughkeepsie, NY 12601

E. Ahmet Tonak Simon's Rock of Bard College, Division of Social Sciences, Great Barrington, MA 01230

\section{Editorial Coordinator:}

Haldun Gülalp SUNY-Binghamton Department of Sociology, Binghamton, NY 13901

\section{Book Review Editor:}

Reşat Kasaba University of Washington, JSIS Thomson DR-05, Seattle, WA 98195

New Perspectives on Turkey is published twice a year and sponsored by Simon's Rock of Bard College, Great Barrington, MA. Annual subscription rate is $\$ 10.00$ for individuals ( $\$ 6.00$ single copies). $\$ 20.00$ for libraries and institutions. Subscribers outside North America should add $\$ 1.00$ for surface mail and $\$ 2.50$ for air mail per issue. Correspondence regarding subscriptions should be sent to the managing editors. See back cover for information regarding submissions. Copvright (C) 1987 by Simon ${ }^{\circ}$ Rock of Bard College. 


\title{
NEW PERSPECTIVES ON TURKEY
}

\author{
Fall $1987 \quad$ No. 1
}

\section{CONTENTS}

Foreword

\section{ARTICLES}

Agriculture and Rural Life in the Ottoman Empire

$$
\text { (ca 1500-1878) }
$$

Suraiya Faroqhi 3

New Political Parties and the Problems of

Development in Turkey

Birol Yeşilada 35

The Status and Significance of the Theory of

Social and Cultural Pluralism

James A. Monsonis

63

REVIEW ARTICLE

Turkish Agrarian Debate: New Arguments or

Old Scores

Zülküf Aydın

BOOK REVIEWS

David Barchard, Turkey and the West

Ronnie Margulies 109

Zülküf Aydın, Underdevelopment and Rural Structures

in Southeastern Turkey: Gısııs and Kalhana Leyla Neyzi 111 